\title{
Nongerminomatous Germ Cell Tumor
}

National Cancer Institute

\section{Source}

National Cancer Institute. Nongerminomatous Germ Cell Tumor. NCI Thesaurus. Code C121619.

A term that refers to teratoma, embryonal carcinoma, yolk sac tumor, choriocarcinoma, or mixed forms of these tumors. 